\title{
Institutional Differentiation of Public Service Provision in Germany: Corporatisation, Privatisation and Re-Municipalisation
}

\author{
Benjamin Friedländer, Manfred Röber, \\ and Christina Schaefer
}

\section{INTRODUCTION}

Recent decades have seen an increasing transfer of public service ${ }^{1}$ provision to institutions outside the core administration. This process of differentiation in the performance of public tasks has led to significant changes in the institutional landscape. The shift from the model of the 'caring welfare state' towards the model of the 'enabling and ensuring state' has fundamentally changed the understanding of the state in Germany. Public services are no longer exclusively and directly delivered

B. Friedländer $(\bowtie) \bullet$ C. Schaefer

Helmut Schmidt University, Hamburg, Germany

e-mail: benjamin.friedlaender@hsu-hh.de; christina.schaefer@hsu-hh.de

M. Röber

University of Leipzig, Leipzig, Germany

e-mail: roeber@wifa.uni-leipzig.de

(C) The Author(s) 2021

291

S. Kuhlmann et al. (eds.), Public Administration in Germany,

Governance and Public Management,

https://doi.org/10.1007/978-3-030-53697-8_17 
by the core administration of the state and municipalities, but also by external (not-for-profit and private) organisations.

The idea behind the model of the 'enabling and ensuring state' is the division into different levels of responsibility for service provision (guaranteeing, providing, financing and serving as a fallback provider; see: Schuppert 2005). This kind of division of responsibilities results in a complex network of public and private actors (which can be described as principal-agent relationships).

Following the arguments of the Public Choice Theory, the reasons for the institutional differentiation in Germany are, on the one hand, criticism of the inefficiency and ineffectiveness of public administration as a monopolistic service provider. On the other hand, there have been political tendencies to push the state back in favour of the private sector (in conjunction with anti-bureaucratic, market-oriented reforms for the remaining state and more 'choice' for citizens) and to divide monolithic-bureaucratic administrations into smaller decentralised units.

Within the framework of the enabling state model, the state has a wide range of institutional arrangements to choose from in order to ensure the performance of public tasks. Public services can be produced and delivered by (cf. Reichard and Röber 2019): ${ }^{2}$

- different departments and units of the public core administration (in-house provision);

- corporatisation, which can be understood as the institutional transfer of tasks from administrative units into companies. Corporations remain completely or partially in state or municipal ownership. A distinction can be made between the following options:

- partly independent institution without its own legal status and with rather limited autonomy (e.g. government-operated/semiautonomous agency/utility) (Eigenbetrieb),

- public institution and foundation under public law (Anstalt und Stiftung des öffentlichen Rechts),

- local administrative association as single-purpose agency which is an association of several local authorities for the joint performance of a specific public task (e.g. water supply/sewerage or local public transportation) (Zweckverband),

- legally and organisationally independent institution which, although still fully or partly owned by the state or municipality, has a minimum degree of managerial autonomy as state- or municipal-owned enterprise (formelle Privatisierung). It usually 
takes place in the private legal form of the limited liability company (Gesellschaft mit beschränkter Haftung) or joint-stock company (Aktiengesellschaft),

- hybrid institution, such as a corporation jointly owned by public and private shareholders (also called institutional public-privatepartnership (PPP));

- outsourcing or contracting out (funktionale Privatisierung) for which the public sector withdraws partially or completely from the provision of services by transferring a task or part of it to private organisations for a fixed period of time, but still retains the responsibility for ensuring these services (e.g. awarding of concessions). A special form of outsourcing is contractual PPPs, which means the transfer of services or functions to private companies based on contracts for a limited time period. The private organisation will generally be a commercial private enterprise, but a private not-for-profit organisation can also be considered (e.g. provision of social services by welfare associations), and

- privatisation as the complete transfer of a public task to private entities (materielle Privatisierung) in which the state relieves itself of all responsibility and has only a minor influence on the scope of tasks in the form of regulation (full retreat of the state). ${ }^{3}$

After decades of privatising public services, several municipalities have terminated concession contracts which were formerly awarded to external private suppliers or have-in a very few cases-bought back utilities. Therefore, we observe a debate about the advantages of publicly provided services vis-à- $\boldsymbol{p}$ is privatised ones at the local level. Re-municipalisationwhich is about returning previously (in most cases, functionally) privatised public supply and disposal services to local authorities- has been on the agenda of local politicians for the last ten years.

If the state or a local authority wants to make a decision about which institutional arrangement should be used to perform a public task, the criteria of strategic relevance (i.e. the importance of fulfilling a task for implementing policy objectives), the specificity of resources (i.e. the extent of the exclusivity of public resources which are necessary for the provision of services compared to an alternative use of resource) and the cost-effectiveness of task performance by comparing production costs and transaction costs (e.g. for contract initiation, coordination and monitoring) of 
different institutional arrangements ${ }^{4}$ should be taken into consideration (Warm et al. 2018). Taking these fundamentals of institutional economics into account, there is - as mentioned above- a wide range of organisational options for the provision of public services, namely corporatisation, outsourcing, privatisation and re-municipalisation. These four different options will be outlined in the next section with regard to their objectives, advantages and disadvantages as well as selected empirical findings and trends in Germany.

\section{Service Provision Between Corporatisation, Outsourcing, Privatisation and Re-municipalisation}

\subsection{Corporatisation}

According to the calculations of the German Federal Statistical Office, the total number of corporations which are fully or partly owned by public authorities at federal, state and local level is round about $15,000 .^{5}$ The majority of these corporations operate at local level (approximately 90 per cent). About two-thirds of the federal workforce and about half of the municipal employees are employed in these corporations. State-owned enterprises are responsible for more than half of the public sector's investments. The debt ratio of these enterprises is often even higher than that of the core administration. Approximately one-third of these institutions are organised under public law in the form of government-operated/ semi-autonomous utilities, public institutions and foundations under public law or local administrative associations, which are under public law and owned by several local authorities. Almost two-thirds are private-law types of corporatisation mostly in the form of a limited liability company and a joint-stock company (German Federal Statistical Office 2014; German Institute for Economic Research 2017; Hesse et al. 2017; Kuhlmann and Wollmann 2019). The legal form of the limited liability company predominates because, unlike a joint-stock company, this form enables the public owner to exert more influence on corporate strategies and business plans through articles of association (Gesellschaftsvertrag), assembly of owners (Gesellschafterversammlung) and owner instruction (Gesellschafteranweisung).

The aim of corporatisation, that is the transformation of administrative units into companies, is to enable these newly established public enterprises to act more flexibly and independently. This should relieve the core 
administration of purely operational tasks and the provision of services and position it more strongly as a strategic control unit. As a corporatisation can often focus on a single task (similar to the single-purpose agencies in Great Britain), it is expected that their formation will lead to greater professionalism and stability in the fulfilment of tasks (Reichard and Röber 2019).

Corporatisation can also be a matter of relieving political entities by pulling politically controversial issues out of the 'line of fire' of everyday party politics. Especially in the creation of companies under private law, the circumvention of public services and budget law or bureaucratic procurement law is often a motive. Moreover, there is no doubt that hidden motives also play a role. On the one hand, corporatisation can be used to 'hide' loans and thereby conceal public debt ('shadow budgets'). Stateowned enterprises hold nearly 38 per cent of the state's total debt. At the local level, approximately 60 per cent of all municipal debts relate to their municipal-owned enterprises (Schaefer and Friedländer 2019). On the other hand, it can be very tempting to provide distinguished party members with lucrative and well-paid posts or to use these enterprises for partypolitical manoeuvring (Ennser-Jedenastik 2014; Schröter and Röber 2017).

Although it is difficult to empirically prove that corporatisation has led to an increase in efficiency and flexibility, some research results suggest that such effects have been produced-but not to the extent initially assumed (e.g. Voorn et al. 2017; Lindlbauer et al. 2015; Mühlenkamp 2015). In addition, the necessarily formal communication structures between the public owner and its corporation (e.g. in the case of a limited liability company through the above-mentioned mechanism) as well as new requirements for accountability seem to have increased the transparency of decision-making processes (Schröter and Röber 2017). Moreover, in many cases, a certain cultural change from being less bureaucratic to being more entrepreneurial could be observed (Reichard and Röber 2019).

However, corporatisation can also have some negative consequences. The process of corporatisation in recent decades has resulted in a fragmented organisational landscape. Particularly in large German cities, we find highly complex corporate structures with hundreds of municipal holdings (e.g. the city of Frankfurt am Main with more than 540 municipal holdings), which are hard to control and steer solely by the traditional bureaucratic concepts of hierarchy and planning. In some cases, corporations and their managers enjoy too much autonomy, leading to increasing inconsistencies between local policy objectives and corporate purpose. 
Centrifugal dynamics can give rise to serious steering and control problems for local authorities. In addition, experiences at the local level show that performance information is insufficiently used for the control of the described corporate structures, so that important prerequisites for an effective holdings management are often still missing (Friedländer 2019; Wollmann 2016; see Sect. 3). Overall, decisions on corporatisation should be carefully prepared and weighed up to see whether the benefits of enhanced autonomy are appropriate to the loss of steering and control by public authorities.

A special type of corporatisation is institutional PPPs, which are under private law and in a mixed public-private ownership (Duffield 2010). The influence of the two owners on the company's policy formally depends on the size of their capital shares. With a few exceptions, there is a huge lack of reliable statistical data available for this type of enterprise. Based on the analysis of holdings reports, it is assumed that about two-thirds of companies at the federal and state level and nearly 40 per cent of all municipal corporations are institutional PPPs (Reichard 2016 with further references). Due to their mixed ownership, institutional PPPs differ from other forms of corporatisation in certain aspects, insofar as the two owner groups have different interests, goals, core competencies and organisational cultures. These 'trade-offs' between public and private ownership require complex modes of coordination, which can lead to extensive negotiation processes. Success in coordination efforts very much depends on how well both sides are able to tolerate different cultural imprints and competencies (e.g. basic understanding of the public interest and political decisionmaking processes, managerial skills or competencies in inter-sectoral cooperation) and how they can harmonise these special properties with each other (Röber and Schröter 2016).

\subsection{Outsourcing}

The basic idea behind the outsourcing of public tasks to private actors (also referred to as contracting out or functional privatisation) is that public administration can concentrate on its politically defined core functions and be relieved of the burden of providing services that can be produced in a better quality and more cost-effectively by other-private-organisations ('principle of subsidiarity'). In the case of 'outsourcing', a service contract is concluded between the contracting authority and the private 
contractor. The responsibility for ensuring the service provision remains with the state (for the following, see: Röber 2018).

In Germany there is a long tradition-in contrast to unitary welfare states - of involving not-for-profit and private institutions in the provision of public services, such as in the areas of healthcare and social services (Kuhlmann and Wollmann 2019; Grohs 2014). Moreover, numerous services (e.g. supply and disposal services), internal administrative services and annexe tasks (e.g. cleaning services) have been outsourced to private companies since the 1980s.

The main motives for outsourcing public tasks and services to private actors-particularly in the light of the challenging budgetary situation of many local authorities - are similar to those of corporatisation. It is also expected that costs of public services can be reduced by enabling private actors to be more productive due to specialisation and higher levels of efficiency as well as by lower wage levels. Beyond that, ideological convictions continue to contribute to the existence of preferences for private service providers (for more details, see below on privatisation).

Although there are no systematic and comprehensive empirical studies on the consequences of outsourcing, some experiences suggest that from the citizens' point of view quality of service provision may decline (Dahlström et al. 2018). In addition, comparative studies tend to point to similar effects in the case of corporatisation (Pollitt and Talbot 2004) including cautious assessments that outsourcing can reduce costs under certain conditions, although there is so far insufficient empirical evidence for stronger effects on government spending behaviour (Alonso et al. 2015).

However, when making estimates of cost reduction it should be noted that potential-but often rather short-term-effects must be compared with the transaction costs associated with the outsourcing process (i.e. cost of awarding, contract design, monitoring and renegotiation). Furthermore, public authorities should avoid becoming dependent on market-dominating private providers. It is advisable for the public sector to maintain a minimum of relevant 'production know-how' as this can prevent information asymmetries between the public contracting authority and the private service provider. This also creates the possibility of still being able to competently assess the services of the private supplier with regard to their price-performance ratio (cf. Röber 2018).

After a relatively strong trend of outsourcing over the past twenty years, this institutional arrangement is now being regarded with increasing 
scepticism. In many cases, it was not possible to meet the savings expectations, so now there is a tendency to return to more public arrangements (see below on re-municipalisation). Outsourcing of public services can, however, be a reasonable alternative to in-house provision as long as the service is suitable (e.g. in terms of low strategic relevance or low specificity), easy to describe and easy to measure. Furthermore, the contract design should ensure successful control, and the contracting authority should be in a position to constantly monitor the process of service provision. Finally, it is important that a sufficient degree of competition exists.

These requirements become even more obvious when it comes to contractual PPPs that represent a specific form of outsourcing. Contractual PPPs are contractual agreements that allow for the transfer of services or functions to private companies typically based on long-term contracts for a period of twenty to thirty years (Duffield 2010). In Germany, they are most frequently used for physical infrastructure projects in the social sector, such as schools, hospitals or sports facilities. Based on previous experiences, this form of outsourcing has become controversial. Although contractual PPPs are mostly justified with possible efficiency benefits, there are, so far, no reliable empirical findings to suggest these efficiency gains have been made. As a result, relatively few new PPP projects in building and road construction have been launched in Germany since 2012.

Contractual PPPs tend to involve high transaction costs as the often very complex and long-term contracts require extensive adjustments and renegotiations. The theoretical concept of 'incomplete contracts' - as the key to the economic understanding of contractual PPPs-implies that, due to bounded rationalities, not all actions and their consequences can be adequately regulated for the future and that the state or a local authority runs a high risk of bearing these unregulated consequences (e.g. higher costs in the operating phase because of savings or deficiencies in the construction phase). Under these circumstances, the bundling of the different phases of a PPP life cycle, that is from planning, construction, operation to recovery, can increase efficiency and is therefore recommended for such projects. Unfortunately, in most cases, this life cycle approach is not consistently followed in practice.

\subsection{Privatisation}

Looking at privatisation-as the complete transfer of public tasks and public ownership to private entities-from a historical perspective, it can be 
noted that since the 1970s-not only in Germany but in all OECD countries-the idea of the welfare state and its institutions has come under pressure due to obvious, but sometimes only perceived, inefficiencies of public institutions ('state failure'). The main explanations offered for state failure are the selfish behaviour of politicians, the budget-maximising behaviour of bureaucrats, the lobbying of powerful interest groups and inappropriate pricing for public services. As a consequence of the assumed state failure-and in line with changing ideologies towards the lean or minimal state-there has been overall stronger support for privatisations in society and politics. Nevertheless, as far as privatisation is concerned, from an international perspective, Germany was among the OECD countries that pursued a cautious privatisation policy. Although there have been some privatisations of assets such as the federal government's industrial holdings, privatisations have been fairly moderate (Sack 2019). The most relevant areas of privatisation are supply and disposal, postal services, telecommunications and housing. At the municipal level, about one-third of municipalities have had experience with rather modest privatisation projects-especially in the energy and waste sector. In the last two decades, however, the policy of the European Commission for further liberalisation has increased pressure considerably (Röber 2018).

Similar to outsourcing, considerations on privatisation are primarily concerned with financial objectives (cost reduction and budget relief). In addition, however, general ideological positions ('private enterprises basically make everything better and cheaper') as well as economic and regulatory motives have played a role and fostered the private sector.

The effects of privatisation are still the subject of controversial discussion, not least because empirical studies produce mixed results. These controversies relate to different assessments of cost reductions, deterioration in quality, price increases, deterioration in working conditions, the formation of oligopolies in the markets of public services, externalisation of economic, social and ecological risks as well as adverse effects on the democratic control.

In principle, privatisation as the complete transfer of public tasks and public ownership to private entities means that a task loses its 'public' character. It can only be influenced to a limited extent by the state through regulatory policies such as general legislation and regulatory supervision. For this reason, the decisions to privatise have more serious consequences than those to outsource public tasks for a limited period of time. An important prerequisite for a successful privatisation policy is therefore that 
the state is not pushed back and undermined in its regulatory functions, but is in a position to set rules and-if necessary-to enforce them.

Against the background of current studies on privatisation, it should be noted, particularly in the context of public services, that ownership-as a regulatory parameter-has lost its importance. Much more important in terms of regulatory policy than the question of ownership - and the resulting advocacy or rejection of privatisation-is the question of how competitive structures and regulatory regimes can be created in which public and private enterprises can operate for the benefit of society and the citizens, without this leading to misallocations, loss of efficiency or abuse of power (see Sect. 3).

\subsection{Re-municipalisation}

More recently, we observe an increasing scepticism about privatisation projects. In the last few years, there has been growing citizen resistance to planned municipal privatisations, and some municipalities have terminated concession contracts which were formerly awarded to external private suppliers or have-in a very few cases-bought back utilities (Bönker et al. 2016).

In other words, re-municipalisation is about returning previously (in most cases, functionally) privatised public supply and disposal services to local authorities. Consequently, it is an issue related to previous privatisation decisions. Re-municipalisation is a possible result of the revaluation of choice options in the light of former experiences with privatisation programmes.

Apart from other reasons (e.g. ensuring sufficient control of service provision, achieving synergies in municipal corporate structures and socioeconomic reasons, such as contributing to regional employment policies), the global financial crisis was, without doubt, a strong driver for such a reappraisal as the neoliberal dogma of private sector supremacy has been severely damaged. Furthermore, growing doubts persist about the merits of privatisation. Potential reasons for the 'municipalisation-renaissance' are obvious failures of privatisation, anxieties of citizens, stronger self-confidence of local authorities in running their services efficiently and effectively, and increasing fears that the idea of local self-government could be hollowed out if more and more services were transferred to private entities that cannot be controlled politically (Friedländer and Röber 2016; Schaefer and Theuvsen 2012). 
Against the background of this political discourse, a process began in Germany about twenty years ago-especially at the municipal level-to reverse outsourcing and privatisation, at least partially. As a result of this process, an increasing importance of public enterprises can be observed. Between 2000 and 2013, the number of public funds, utilities and enterprises rose steadily by approximately 25 per cent from roundabout 12,240 to-as already mentioned-approximately 15,000 (Hesse et al. 2017).

Some evidence on re-municipalisation can mainly be observed in the energy sector. Between 2007 and 2012, more than 160 concessions were taken over by municipalities or municipal companies. A current study has identified seventy-two newly founded municipal energy utilities in the period from 2005 (Wagner and Berlo 2015). In the period from 2000 to 2011 , sales revenues of municipal energy utilities rose from $€ 51.9$ billion to $€ 114.9$ billion (179 per cent). Thus, their share of nominal GDP has more than doubled (Monopoly Commission 2013).

The concerns of many local authorities that their own utilities could not withstand competition from private energy suppliers have been diminished. Municipalities that privatised large parts of their energy supply in the early 1990s are becoming increasingly aware of the lack of influence on the supply infrastructure and urban development. The dynamic of remunicipalisation was mainly fuelled by two factors: first, the development of energy from renewable resources and second, the expiry of existing electricity and gas concessions. The share of renewable energy in Germany's total heat and electricity consumption is to increase from 20 per cent in 2020 to 60 per cent by 2050 - accompanied by a 50 per cent improvement in energy efficiency. This implies a tendency towards more decentralisation in power generation with better chances for municipal public utilities to enter/re-enter the energy market. Experts assume that the trend towards re-established or newly established municipal utilities will continue. However, the takeover of distribution networks will tend to decline in the coming years due to the decreasing number of expiring concessions (Libbe 2013).

The picture in waste management is quite similar. Here we observe an increase in municipal provision. The absolute revenues of public waste disposal services increased between 2001 and 2011 by about $€ 4.6$ billion (growth rate of 33.7 per cent) (Monopoly Commission 2013). Empirical findings show that in recent years some local authorities (especially smaller cities and districts) have opted for in-house provision rather than outsourcing (Opphard et al. 2010). In other municipal service areas, the 
emphasis on re-municipalisation is rather low. This applies, for instance, in the water and sewage industry and in the public transport sector. Most service providers in these sectors are still public and the ratio of privatised corporations is very low.

Although the sectoral re-municipalisation tendencies go beyond the individual projects, no visible general trend towards re-municipalisation can be observed in Germany. It remains unclear to what extent these developments are of a long-lasting nature, that is whether they will tend to spread further or are more likely to decline. This can be said for Germany and other European countries where different developments can also be observed in the various sectors of public services and where the diversity and differentiation of the institutional landscape is also increasing rather than decreasing (Friedländer and Röber 2016; Wollmann 2016).

\section{LESSONS LEARNED}

Each of the above-mentioned institutional arrangements has important consequences for steering, governance and management requirements, which will continue to increase rather than decrease. Practitioners facing these complex issues have to deal with various actors who can differ greatly in their goals, risk preferences, logic of action, core competencies and organisational cultures. In addition, all these issues involve micropolitics that are difficult to influence but are, in many cases, crucial.

Better management in decentralised or external institutions with no corresponding capabilities in public authorities and politics will most probably widen the skills gap, which can, in turn, lead to an uncontrollable autonomy of these institutions and too little influence on public service provision. Recent research results show that it is becoming more difficult for public authorities to strike a balance between 'freedom to manage' (e.g. managerial autonomy of corporations) on the one hand, and political control (e.g. enforcement of policy objectives) on the other, through different forms of coordination as well as embedded or connected modes, including appropriate incentive and sanction mechanisms as well as quality standards, which fit exactly to a specific organisational setting (Friedländer 2019). This requires a system of integrated coordination and management, which focusses on the core administration as well as on the various forms of decentralised and external institutions or service providers.

Looking in particular at the relationship between municipalities and their corporations, municipal codes require that local authorities exert a 
reasonable influence on these institutions. As a result, most German municipalities have a corporate governance or holdings management system that includes all the tasks, institutions, actors and administrative units involved in enabling a municipality as an owner to take responsibility for the control of its enterprises. This system also involves the activities of supervisory bodies and representatives of the shareholders within municipal corporations as well as political committees responsible for finance and holdings (Ausschüsse für Finanzen und Beteiligungen) (similar regulatory mechanisms exist at federal and state level).

Some municipal charters additionally require the establishment of an administrative unit for holdings management, which can be arranged very differently within or outside the municipal administration. In most cases, this unit is either part of the finance department or organised as a separate department or located as a staff position directly with the mayor (central organisation). Some cities use a decentralised form in which holdings management is carried out by the specialised administrative departments (e.g. housing, water and energy) or a combination of both, that is a centralised/decentralised form. In a few cities, holdings management is not part of the core administration but is carried out externally by an institution which is completely in municipal ownership (Schaefer 2004).

Apart from this, the duality of supervisory board and management board applies to the majority of municipal-owned enterprises. The German corporate law subjects owners of a limited liability company of a certain size to the rules that apply to joint stock companies by introducing a dual structure of governing boards. Moreover, individual German states require local governments to establish supervisory boards - regardless of the size of the corporation-if they opt to pursue their economic activities in the form of a private-law company. Therefore, the composition of board membership, and the selection, recruitment and appointment of individual board members are highly significant matters in the management and control of public enterprises (Schröter and Röber 2017).

In summary, the institutional options for providing public services have become highly differentiated and have, of course, their own specific advantages and disadvantages. If the public sector does not opt for in-house provision, a key challenge will be exerting an appropriate level of influence over the provision of services, which normally diminishes significantly when taking the 'corporatisation' to 'privatisation' option. It is necessary to ensure that an institutional arrangement guarantees an accessible, 
qualitatively appropriate and financially stable fulfilment of tasks. And finally, the service must be provided efficiently.

However, valid assessments of the efficiency of the various institutional options are difficult to make as such organisational solutions often have a time horizon of between twenty and thirty years. For this reason, the costs, effects and behaviour of the various actors can only be evaluated with a considerable degree of uncertainty. Furthermore, as already mentioned, transaction costs associated with the planning, control and monitoring of a particular arrangement of service provision play a significant role in efficiency assessments. Therefore, these 'control costs' should not be ignored.

From a more fundamental position, it should be emphasised that the debate about public versus private service provision might now be a fairly outdated discussion because both options only differ from each other in terms of property. Hence, the debate is primarily focussed on ownership issues - while questions of appropriate market structures and regulation are neglected. This only leads to an exchange of more or less ideological convictions. It is most likely that ownership issues are overestimated and less relevant for the efficiency and effectiveness of service provision.

An important starting point for correcting these misconceptions would be to take a somewhat more functional perspective rather than the traditional institutional and ownership-based perspective (state-owned versus private enterprises). Following this idea, it would be useful to have serious debates about private or public service provision regarding public tasks and services, and about which institutional arrangements and organisational structures are the most suitable for performing these tasks and public services. The brief overview of opportunities and trends in the provision of public services shows that the institutional arrangements for services provision vary, each option has its own specific advantages and disadvantages and that there is no one-size-fits-all solution.

Consequently, the public sector will need to evaluate the respective strengths and weaknesses on a case-by-case basis. In essence, it is about the conscious choice and design of the institutional structure and its steering. Decisions about organisational arrangements — which are ultimately policy decisions - make it absolutely necessary to use procedures enabling practitioners to systematically analyse current framework conditions and objectives as well as consider all possible institutional options. ${ }^{6}$ 
Table 17.1 Public funds, institutions and enterprises by legal form and authority

Federation $\begin{gathered}\text { Federal Municipalities Total } \\ \text { states }\end{gathered}$

\section{Civil Law}

Joint stock company

Limited liability company

Limited partnership with a limited

liability company as general partner

Other (e.g. associations)

Total Civil Law

Public Law

Government-operated/semi-autonomous

utility

Local administrative associations

Institution under public law

Foundation under public law

Other corporations under public law

Total Public Law

Total

$\begin{array}{rrrr}11 & 35 & 194 & 240 \\ 181 & 842 & 7758 & 8781 \\ 7 & 111 & 489 & 607 \\ & & & \\ 3 & 9 & 87 & 99 \\ 202 & 997 & 8528 & 9727 \\ & & & \\ 5 & 230 & 3522 & 3757 \\ & & & \\ - & - & 1102 & 1102 \\ 9 & 86 & 265 & 360 \\ 1 & 36 & 4 & 41 \\ 2 & 39 & 20 & 61 \\ 17 & 391 & 4913 & 5321 \\ 219 & 1388 & 13,441 & 15,048\end{array}$

Source: Authors' own calculations, based on German Federal Statistical Office 2014, see: Warm et al. (2018)

\section{Notes}

1. The German term for these services is Daseinsvorsorge and covers technical infrastructure (traffic and transport facilities, gas, water and electricity supply, refuse collection, sewage disposal, telecommunications) as well as social infrastructure, like healthcare, hospitals, childcare, care for the elderly, educational and cultural institutions.

2. For comparability of the internationally common distinction between different agency types, see: van Thiel (2012).

3. We can also distinguish the form of privatisation as asset sale, which refers to the sale of enterprises, property assets, land and so on. This form of privatisation plays a subordinate role in this chapter.

4. Due to the effort required for coordination and monitoring, transaction costs normally increase from 'in-house provision' to the 'outsourcing-solution'.

5. For details, see Table 17.1. In some documents, the figures vary slightly due to the reference year and the methodology used for public finance and public service personnel statistics ('shell concept') (cf. Schaefer and Friedländer 2019) 
6. For these decisions, the Local Governments' Joint Agency for Administrative Management - an independent consultancy agency organised by voluntary membership of German municipalities, counties, and local authorities with more than 10,000 inhabitants-recommends a five-step procedure (see: KGSt 2010a, b). This procedure, which was developed in collaboration with the author Manfred Röber, is to be understood as a checklist or analytical instrument, which can be used for case-by-case decisions about organisational arrangements.

\section{REFERENCES}

Alonso, J. M., Clifton, J., \& Díaz-Fuentes, D. (2015). Did New Public Management Matter? An Empirical Analysis of the Outsourcing and Decentralisation Effects on Public Sector Size. Public Management Review, $17(5), 643-660$.

Bönker, F., Libbe, J., \& Wollmann, H. (2016). Remunicipalisation Revisited: Long-Term Trends in the Provision of Local Public Services in Germany. In H. Wollmann, I. Kopric, \& G. Marcou (Eds.), Public and Social Services in Europe (pp. 71-85). Houndmills/New York: Palgrave Macmillan.

Dahlström, C., Nistotskaya, M., \& Tyrberg, M. (2018). Outsourcing, Bureaucratic Personnel Quality and Citizen Satisfaction with Public Services. Public Administration, 96, 218-233.

Duffield, C. F. (2010). Different Delivery Models. In G. A. Hodge, C. Greve, \& A. E. Boardman (Eds.), International Handbook on Public-Private Partnerships (pp. 187-215). Cheltenham: Edward Elgar Publishing.

Ennser-Jedenastik, L. (2014). Political Control and Managerial Survival in StateOwned Enterprises. Governance, 27(1), 135-161.

Federal Statistical Office of Germany. (2014). Jahresabschlussstatistik öffentlicher Fonds, Einrichtungen und Unternehmen. Statistisches Bundesamt 2014, Wirtschaft und Statistik (pp. 307-314). Wiesbaden: Self-publisher.

Friedländer, B. (2019). Kommunale Gesamtsteuerung öffentlicher Aufgaben: Bestandsaufnahme, Bewertung und Perspektiven. Wiesbaden: Springer VS.

Friedländer, B., \& Röber, M. (2016). Rekommunalisierung öffentlicher Dienstleistungen. Entwicklungstendenzen in vier europäischen Ländern und organisationspolitische Perspektiven. Verwaltung \& Management, 22(2), 59-67.

German Institute for Economic Research. (2017). Statistics of Annual Accounts of Public Funds, Institutions and Enterprises: 2003-2012, Data Documentation. No. 87. Berlin.

Grohs, S. (2014). Hybrid Organizations in Social Service Delivery in Quasimarkets. The Case of Germany. American Behavioral Scientist, 58(11), 1425-1445. 
Hesse, M., Lenk, T., \& Starke, T. (2017). Investitionen der öffentlichen Hand. Die Rolle der öffentlichen Fonds, Einrichtungen und Unternehmen. Gütersloh: Bertelsmann Stiftung.

KGSt. (2010a). Gutachten Kommunale Organisationspolitik (Vol. 1). Köln: Self-publisher.

KGSt. (2010b). Gutachten Kommunale Organisationspolitik (Vol. 2). Köln: Self-publisher.

Kuhlmann, S., \& Wollmann, H. (2019). Introduction to Comparative Public Administration. Administrative Systems and Reforms in Europe (2nd ed.). Cheltenham/Northampton: Edward Elgar.

Libbe, J. (2013). Rekommunalisierung in Deutschland-eine empirische Bestandsaufnahme. In C. Matecki \& T. Schulten (Eds.), Zurück zur öffentlichen Hand? Chancen und Erfahrungen der Rekommunalisierung (pp. 18-36). Hamburg: VSA Verlag.

Lindlbauer, I., Winter, V., \& Schreyögg, J. (2015). Antecedents and Consequences of Corporatization: An Empirical Analysis of German Public Hospitals. Journal of Public Administration Research and Theory, 26(2), 309-326.

Monopoly Commission. (2013). Eine Wettbewerbsordnung für die Finanzmärkte. Zwanzigstes Hauptgutachten der Monopolkommission gemäß $\$ 44$ Abs. I Satz 1 GWB. Bonn: Self-publisher.

Mühlenkamp, H. (2015). From State to Market Revisited: More Empirical Evidence on the Efficiency of Public (and Privately-owned) Enterprises. Annals of Public and Cooperative Economics, 86(4), 535-557.

Opphard, K., Pohl, W., Utz, J., \& Hölzl, C. (2010). In- und Outsourcing in der kommunalen Abfallwirtschaft. Studie über Make-or-Buy-Entscheidungen. In Heinrich-Böll-Stiftung \& VKS (Eds.), VKS Information (Vol. 75). Berlin: Self-publisher.

Pollitt, C., \& Talbot, C. (Eds.). (2004). Unbundled Government: A Critical Analysis of the Global Trend to Agencies, Quangos and Contractualisation. London \& New York: Routledge.

Reichard, C. (2016). Gemischtwirtschaftliche Unternehmen im europäischen Vergleich. In U. Papenfuß, \& C. Reichard (Eds.), Zeitschrift für öffentliche und gemeinwirtschaftliche Unternehmen/Journal for Public and Nonprofit Services (ZögU) (pp. 10-24), Supplement 48. Baden-Baden: Nomos.

Reichard, C., \& Röber, M. (2019). Organisationspolitische Optionen für öffentliche Aufgaben-Verselbständigung, Auslagerung und Privatisierung. In C. Reichard, S. Veit, \& G. Wewer (Eds.), Handbuch zur Verwaltungsreform (5th ed., pp. 263-274). Wiesbaden: Springer VS.

Röber, M. (2018). Outsourcing und Privatisierung. In R. Voigt (Ed.), Handbuch Staat (pp. 1049-1058). Wiesbaden: Springer VS.

Röber, M., \& Schröter, E. (2016). Gemischtwirtschaftliche Unternehmen: Nicht öffentlich, nicht privat—eine geniale Synthese? In U. Papenfuß, \& C. Reichard 
(Eds.), Zeitschrift für öffentliche und gemeinwirtschaftliche Unternehmen/ Journal for Public and Nonprofit Services (ZögU) (pp. 25-45), Supplement 48. Baden-Baden: Nomos.

Sack, D. (2019). Vom Staat zum Markt. Privatisierung aus politikwissenschaftlicher Perspektive. Wiesbaden: Springer VS.

Schaefer, C. (2004). Steuerung und Kontrolle von Investitionsprozessen. Theoretischer Ansatz und Konkretisierung für das öffentliche Beteiligungscontrolling. Wiesbaden: Deutscher Universitäts-Verlag.

Schaefer, C., \& Friedländer, B. (2019). Finanzierung im öffentlichen Sektor. In C. Reichard, S. Veit, \& G. Wewer (Eds.), Handbuch zur Verwaltungsreform (5th ed., pp. 433-442). Wiesbaden: Springer VS.

Schaefer, C., \& Theuvsen, L. (Eds.). (2012). Renaissance öffentlicher Wirtschaft. Bestandsaufnabme-Kontexte-Perspektiven. Baden-Baden: Nomos.

Schröter, E., \& Röber, M. (2017). Public Managers in Germany: Between Patronage and Professionalism. In Annual Conference of the International Research Society on Public Management 2017. Budapest.

Schuppert, G. F. (Ed.). (2005). Der Gewährleistungsstaat-Ein Leitbild auf dem Prüfstand. Baden-Baden: Nomos.

Van Thiel, S. (2012). Comparing Agencies across Countries. In K. Verhoest, S. van Thiel, G. Bouckaert, \& P. Laegreid (Eds.), Government Agencies: Practices and Lessons from 30 Countries (pp. 18-26). Basingstoke: Palgrave Macmillan.

Voorn, B., van Genugten, M. L., \& van Thiel, S. (2017). The Efficiency and Effectiveness of Municipally Owned Corporations: A Systematic Review. Local Government Studies, 43(5), 820-841.

Wagner, O., \& Berlo, K. (2015). The Wave of Remunicipalisation of Energy Networks and Supply in Germany-the Establishment of 72 New Municipal Power Utilities. In ECEEE Summer Study Proceedings (pp. 559-569).

Warm, S., Schaefer, C., \& Friedländer, B. (2018). Role and Performance of Public Enterprises: A Case Study on the Strategic Relevance and Specificity of Enterprises at the German Federal Level. Annals of Public and Cooperative Economics, 89(3), 543-577.

Wollmann, H. (2016). Provision of Public and Social Services in European Countries: From Public Sector to Marketization and Reverse or-, What Next? In S. Kuhlmann \& G. Bouckaert (Eds.), Local Public Sector Reforms in Times of Crisis: National Trajectories and International Comparisons (pp. 187-204). Basingstoke: Palgrave Macmillan. 
Open Access This chapter is licensed under the terms of the Creative Commons Attribution 4.0 International License (http://creativecommons.org/licenses/ by $/ 4.0 /$ ), which permits use, sharing, adaptation, distribution and reproduction in any medium or format, as long as you give appropriate credit to the original author(s) and the source, provide a link to the Creative Commons licence and indicate if changes were made.

The images or other third party material in this chapter are included in the chapter's Creative Commons licence, unless indicated otherwise in a credit line to the material. If material is not included in the chapter's Creative Commons licence and your intended use is not permitted by statutory regulation or exceeds the permitted use, you will need to obtain permission directly from the copyright holder. 